\title{
角柱近傍の平板が流れ場と音場に及ぼす影響*
}

\author{
奥津 泰彦 ${ }^{* 1}$ ，濱本 直樹 ${ }^{* 2}$, 土井 克則 ${ }^{* 3}$ ， 中村 佳朗 ${ }^{* 3}$
}

\section{Effects of Flat Plate Placed near Square Cylinder on Flow and Sound Fields}

\author{
Yasuhiko OKUTSU*1, Naoki HAMAMOTO, Katsunori DOI and Yoshiaki NAKAMURA \\ ${ }^{* 1}$ Vehicle Function Testing Dept. Mitsubishi Motors Corporation \\ Nakashinkiri 1, Hashime-cho, Okazaki-shi, Aichi, 444-8501 Japan
}

In studying the mechanism of aerodynamic noise generated by the body of an automotive vehicle, it is necessary to consider the effects of not only an object in the air flow, but also the body surface located close to the object on the noise. In the present paper, a square cylinder and a flat plate were employed as a test model, and aerodynamic noise in the far field and pressure fluctuations on the flat plate were examined by changing the distance between the square cylinder and the flat plate. A commercial, numerical simulation code based on Lattice Boltzmann Method was used to obtain the data on the flow structure and aeroacoustic properties. In parallel with this numerical simulation, an experiment was conducted with regard to this model. It was found from the experiment that the aeolian sound is generated by Karman vortices when the clearance between the square cylinder and the flat plate is $60 \%$ height or more of the square cylinder. In addition, the flat plate plays a role of an acoustic reflection surface. The effect of the flat plate on the far field noise level appears in the frequency region with $S t=0.25$ or more, and an increase in the noise level by the acoustic reflection is about $5 \mathrm{~dB}$. Therefore, it is necessary to consider the non-compact acoustic characteristics to estimate the far field noise level.

Key Words : Aerodynamic Noise, Pressure Fluctuations, Interference, Reflection, Numerical Simulation, Experimental Measurement

\section{1. 緒言}

近年，省資源や地球温暖化防止の観点から電気自動車や電動走行可能なハイブリッドカーの普及が著しい。こ れらの車両では，動力源からの騒音レベルが非常に小さいため，従来目立たなかった空力騒音が相対的に顕在化 してきている. 空力騒音は速度の 4 乗〜 8 乗に比例して増大寸ることから, 高速走行時の車室内静肃性を確保す るために，その低減は自動車開発において非常に重要な課題となっている．特に，高周波数帯域の騒音は，低周 波数帯域の騒音よりも音厓ベルは低いが，人間の聴感特性に基づく等ラウドネス曲線(1)が示すように，人間に とって不快に感じられるため，製品開発段階での低減対策が必要となっている.

自動車の空力騒音は，車体表面の段差やドアミラー，ワイパー，ルーフキャリアなど車体や外装部品周りの流 れ場に起因して発生する，自動車の開発においては，車体への部品取り付け位置を変更することで，流れ場を変 化させて空力騒音の低減を図ることが多い。このような背景のもと，自動車を対象とした数值流体解析

(Computational Fluid Dynamics) やマイクロホンアレイなどを用いた風洞実験が行われているが(2)，自動車の車体 表面と取り付け部品の間の距離をパラメータとして流れ場と音場を検証した例は少ない.

本報では, 自動車の外装部品や段差を模擬した角柱とその近傍に設置した車体表面を模擬する平板により構成

\footnotetext{
* 原稿受付 2012 年 10 月 4 日

${ }^{* 1}$ 正員，三菱自動車工業(株) 開発本部機能実験部 ( ( $444-8501$ 愛知県岡崎市橋目町字中新切 1 番地)

*2 三菱自動車工業 (株) 開発本部機能実験部

*3 正員, 名古屋大学大学院工学研究科航空宇宙工学専攻 ( ₹464-8603 愛知県名古屋市千種区不老町 1 番地)

E-mail: yasuhiko.okutsu@mitsubishi-motors.com
} 
された基礎模型を用いて，無響風洞における実験計測と格子ボルツマン法（Lattice Boltzmann Method）に基づく 汎用流体解析ソルバ PowerFLOW を用いた CFD を実施し，角柱-平板間距離の変化が，流れ場と音場にどのよう な影響を及ぼすかについて調べた。

\section{2. 主な記号}

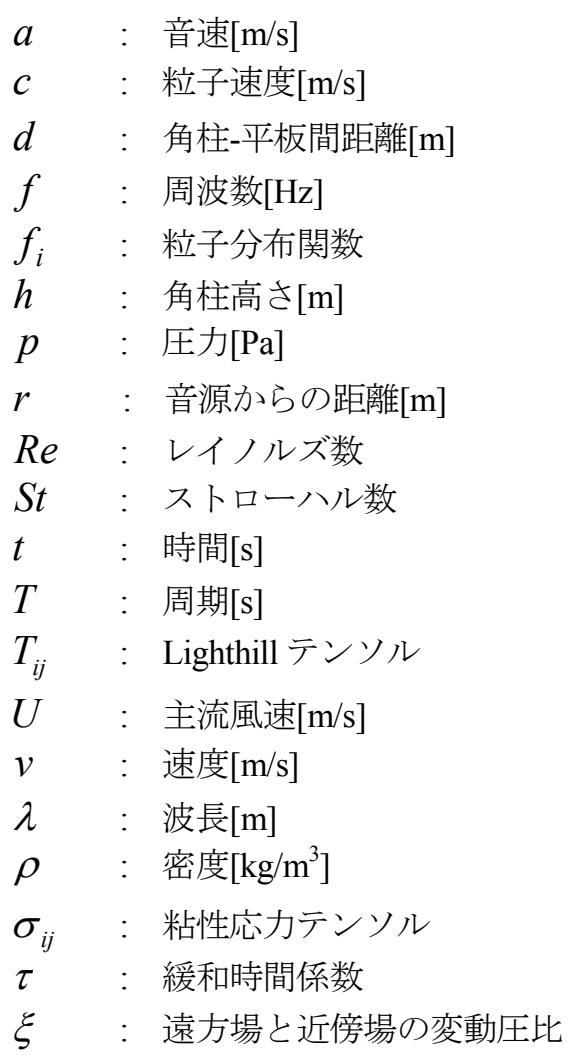

\section{3. 実験装置および方法}

\section{$3 \cdot 1$ 供試基礎模型}

平板近傍に角柱を設置した基礎模型の概略を示す（図 1)。平板は自動車の車体表面を，角柱は車体表面上の段 差やドアミラー，ワイパー，ルーフキャリアなどの外装部品を想定している. 角柱は, 断面が辺長比 $1(h=5 \mathrm{~mm})$ の正四角柱で, スパン方向長さは $40 h$ であり, 角柱-平板間距離 $d$ は任意に変更可能である. 本研究では平板上 に角柱が接している状態 $(d=0)$ を基本モデルとし，角柱-平板間距離 $d$ を角柱高さ $h$ で無次元化した $d / h$ の值 をパラメータとして実験を行った. 具体的には， $d / h=0 ， 0.2 ， 0.4 ， 0.6 ， 0.8 ， 1 ， 2 ， 5$ の 8 ケースを調べた. ま た，流れ場から発生した空力騒音の平板による反射の影響を確認するため，平板なしの条件でも騒音計測を行っ た. 角柱は主流方向に, 気流吹出口から角柱前縁までの距離が $10 h$ となる位置に設置した. 平板の材質はアクリ ルで，厚さ $h$ ， スパン方向長さ $60 h$ ，主流方向長さ $110 h$ である. 境界層の影響を小さくするため，平板前縁を テーパ形状とした. 本基礎模型は無響風洞内に設置した. なお, 本風洞の気流吹出口サイズは $20 h \times 20 h$ あるる.

\section{$3 \cdot 2$ 実験方法}

遠方場騒音の計測位置は, 模型のスパン方向対称断面内で, 吹出口から主流方向に $10.5 h$, 平板から上方に $90 h$ の位置とした. 遠方場騒音の計測には $1 / 2$ インチ自由音場型マイクロホン（B\&K 社製 4190）を，平板表面圧 力変動の計測には $1 / 4$ インチ音圧音場型マイクロホン（B\&K 社製 4938）をそれぞれ使用した. 平板表面圧力変動 
の計測は, 数值解析結果の流れ場の解析精度を確認するために実施した. 計測は, $d / h=0$ の場合に，平板上の 35 箇所の計測孔で行った．計測孔は吹出口から主流方向に $15 h$ の位置より $4 h$ 間隔で 7 列，スパン方向に $3 h$ 間 隔で 5 列設けた (図 1(b))．流れ場の計測は主流風速を $20 \mathrm{~m} / \mathrm{s}$ として行った。なお，騒音および圧力変動の計測デ 一タは FLAT 特性で周波数分析した。

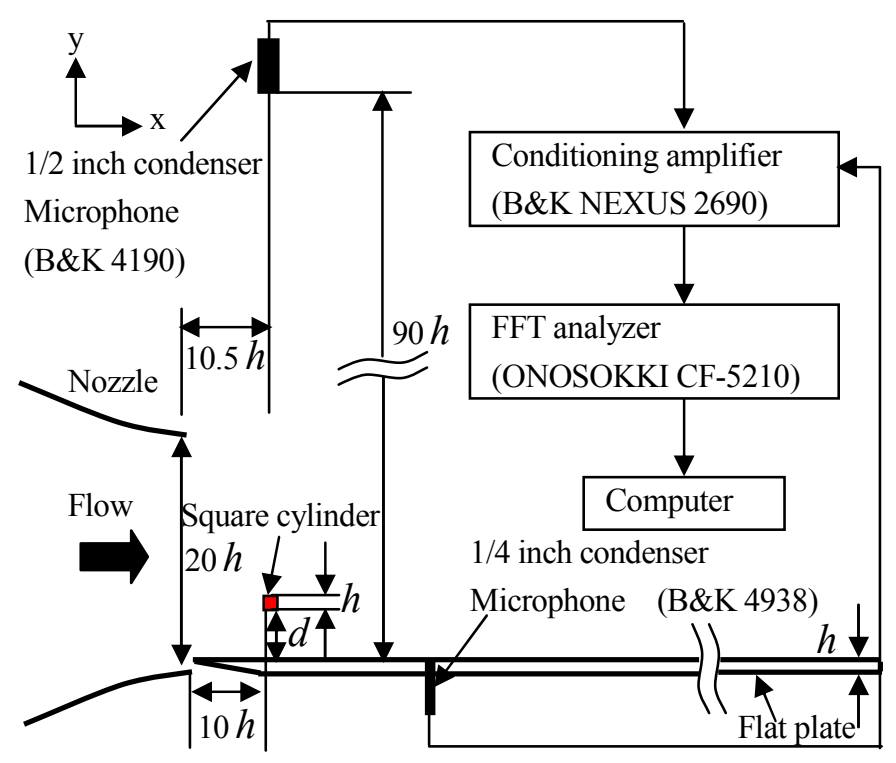

(a) Side view

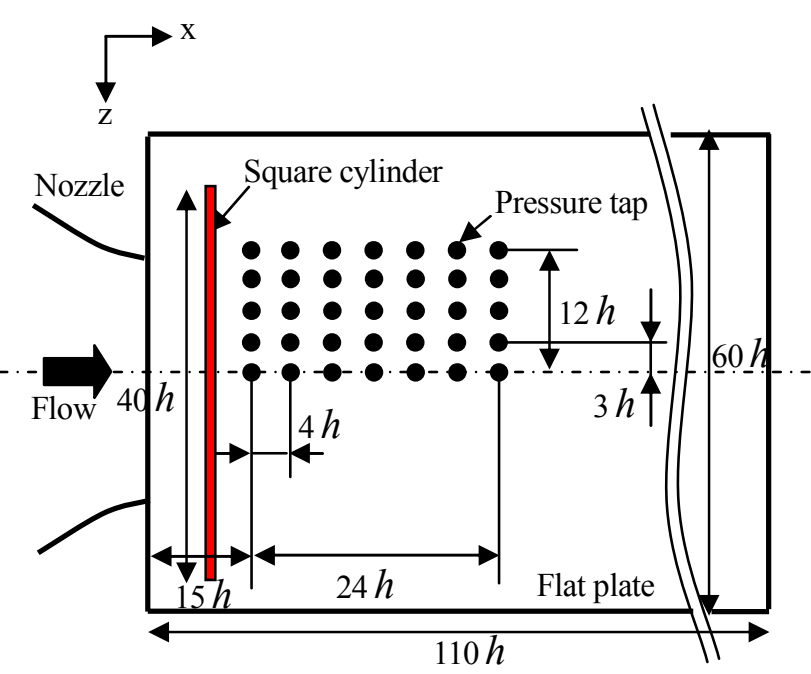

(b) Top view

Fig. 1 Experimental apparatus

\section{4. 数值解析手法}

\section{$4 \cdot 1$ 計算スキーム}

数值解析は，格子ボルツマン法に基づく汎用流体解析ソルバ PowerFLOW を用いて行った．本ソルバは気体分 子運動論の基本となるボルツマン方程式を支配方程式としており，流体分子の集合の粒子分布を解くことで, 複 雑な流体現象を模擬している．粒子分布関数を用いて記述される格子ボルツマン方程式は式（1）で記述され，3 次元 19 速度離散モデルを使用している. 衝突項には, 格子 BGK（Bhatnagar-Gross-Krook）モデルを適用し, 粒子 同士の衝突をモデル化した.

$$
f_{i}\left(\mathbf{x}+c_{i} \Delta t, t+\Delta t\right)-f_{i}(\mathbf{x}, t)=-\frac{1}{\tau}\left[f_{i}(\mathbf{x}, t)-f_{i}^{e q}(\mathbf{x}, t)\right] \quad\{i=0, \ldots, 18\}
$$

ここで, $\mathbf{x}$ は空間の位置ベクトル, $f_{i}^{e q}$ は局所平衡分布関数であり, 添字 $i$ は速度方向を表す. 本解析では, 格 子上で粒子速度が 1 種類のみの粒子分布としている.

\section{$4 \cdot 2$ 計算条件}

計算領域として $1000 h(\mathrm{x}$ 方向 $) \times 950 h(\mathrm{y}$ 方向 $) \times 1000 h(\mathrm{z}$ 方向 $)$ の空間を定義した．境界条件として， $\mathrm{x}$ 方向 上流端の面では，面内の $20 h(\mathrm{y}$ 方向 $) \times 20 h(\mathrm{z}$ 方向)の流入部 (Inlet) に実験と同じ速度の $20 \mathrm{~m} / \mathrm{s}$ の一様流を与え た. 一方, $\mathrm{x}$ 方向の下流端面では, 圧力值を固定し, 速度を外挿した. $\mathrm{y}$ 方向および $\mathrm{z}$ 方向の計算領域端部の面で は， $\mathrm{x}$ 方向下流端と同じく流出条件とした．壁面条件は，角柱と平板上で速度に関しては滑りなし(no slip) とし， 温度に関しては断熱条件とした。 空間の最小格子サイズは $0.5 \mathrm{~mm}$ であり, 最大サイズは $128 \mathrm{~mm}$ とした（図 2 ）。 角柱など物体が設置されている領域から遠方へ向からにつれ空間の格子サイズを段階的に大きくし，これにより

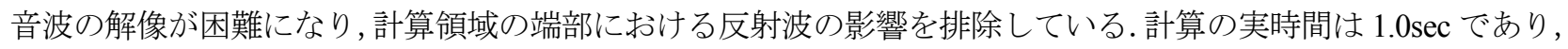




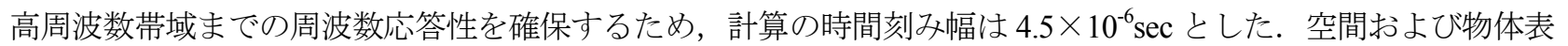
面での計算結果の出力時間は， $0.95 \mathrm{sec} \sim 1.0 \mathrm{sec}$ の $0.05 \mathrm{sec}$ である.ただし，平板上圧力変動計測点に対応する箇所 では, 実験結果と定量的な比較を行うため, 低周波数側の応答性をより低い周波数まで拡大し, 出力時間は $0.3 \mathrm{sec}$

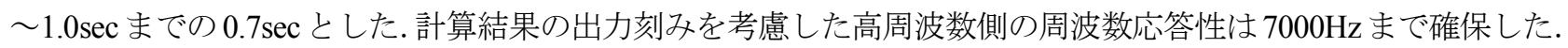
また，計算は角柱-平板間距離 $d / h=0 ， 2 ， 5$ の 3 ケースで実施した.

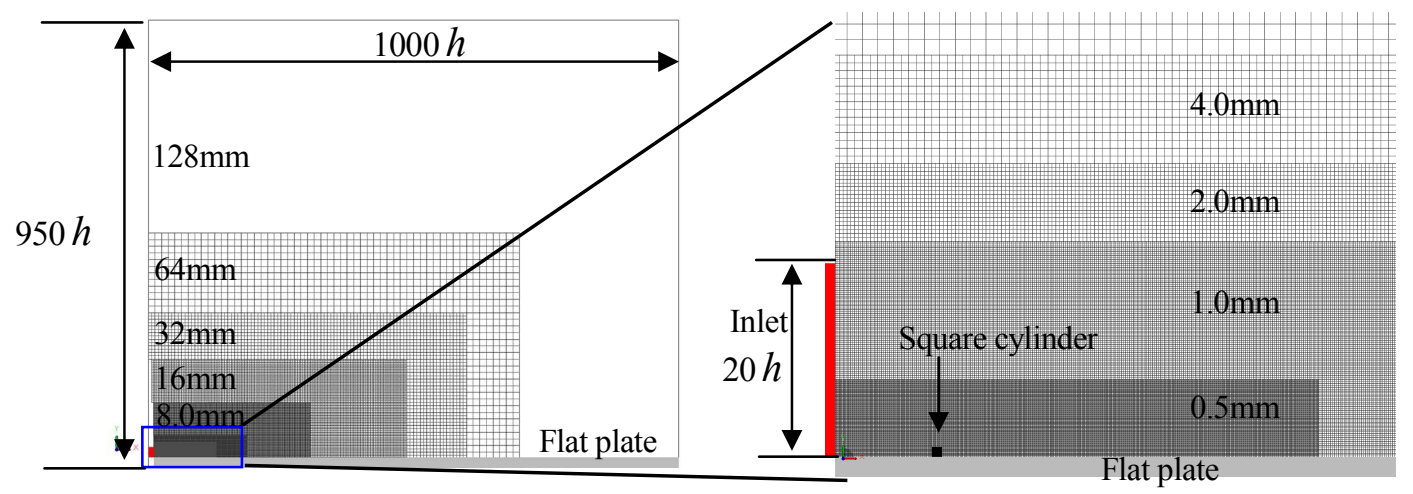

Fig. 2 Computational grids

\section{5. 結果と検証}

\section{$5 \cdot 1$ 遠方場騒音計測結果}

気流中に設置された角柱の後流には，カルマン渦列が形成され，エオルス音が発生することが知られている. しかし, 角柱の近傍に平板が存在する場合, 気流と平板の干渉により, 流れ場が変化すると考えられる. そこで, 基本モデルである $d / h=0$ の場合から，角柱-平板間距離の值を徐々に大きくし，カルマン渦によるエオルス音が 発生する距離を騒音計測実験により調査した。図 3 (a) に平板のみ設置した場合と，角柱-平板間距離を変化し た場合 $(d / h=0,0.2,0.4)$ の合計 4 ケースでの遠方場騒音計測結果を示す。一般に角柱周りの流れ場では，レイ

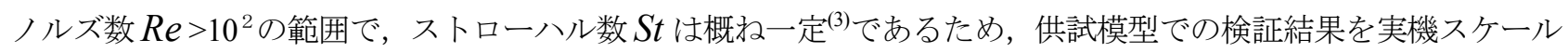
へ換算できるよう，周波数を主流風速 $U$ と角柱高さ $h$ で無次元化したストローハル数で表記する. ストローハル 数は式（2）で表される.

$$
S t=\frac{f \times h}{U}
$$

流れ場中に平板のみを設置した場合に比べて，角柱を平板面上（ $d / h=0 ）$ に設置することで， $S t>1.0$ で $5 \mathrm{~dB} \sim$ $10 \mathrm{~dB}$ 程度音圧レベルが上昇している，これは，角柱を設置することで，気流が乱され，その結果，気流と平板の 干渉が増大したことによるものと推察される．また， $d / h=0.2,0.4$ では，角柱-平板間に隙間が生じるが，カル マン渦による顕著なピーク音は確認できない. しかし, $S t>0.90$ の高周波数帯域では, 音圧レベルが大きく上昇 している.

さて, 図 3 (b) に示すように, 距離がもう少し大きくなって, $d / h=0.6$ の場合には, $S t=0.14$ および 0.28 付 近にピーク音が発生し,$d / h \geq 0.6$ ではこのピーク音が維持される. $S t=0.14$ で確認できるピーク音は, 断面辺 長比が 1 の角柱後流のカルマン渦列から発生する 1 次ピークのストローハル数 $S t=0.13^{(3)}$ と概ね一致する.このこ とから遠方場における騒音スペクトル波形で確認できるピークは周期的に放出されるカルマン渦によるエオルス 音であることがわかる. また, $S t=0.28$ 付近のピーク音はエオルス音の 2 次ピークである. 距離が $d / h \geq 0.6$ で は，角柱-平板間距離によらず，ピーク音の発生周波数と $S t=1.0$ 付近までのスペクトル波形は類似している. し かし，St $>1.0$ では，角柱-平板間距離によって音圧レベルが大きく変化している. 無次元距離が変化することで, 角柱後流に形成される音源からの直接音と平板による反射音の位相差が変化する.これにより，St 数によって音 
圧レベルが大きくなる場合と小さくなる場合が生じると考えられる(4). なお, 無次元距離が 0.6 以上では, $S t>0.50$ の領域における広帯域の音圧レベルも, カルマン渦が形成されない $d / h=0$ の場合より増大寸ることが分かる.
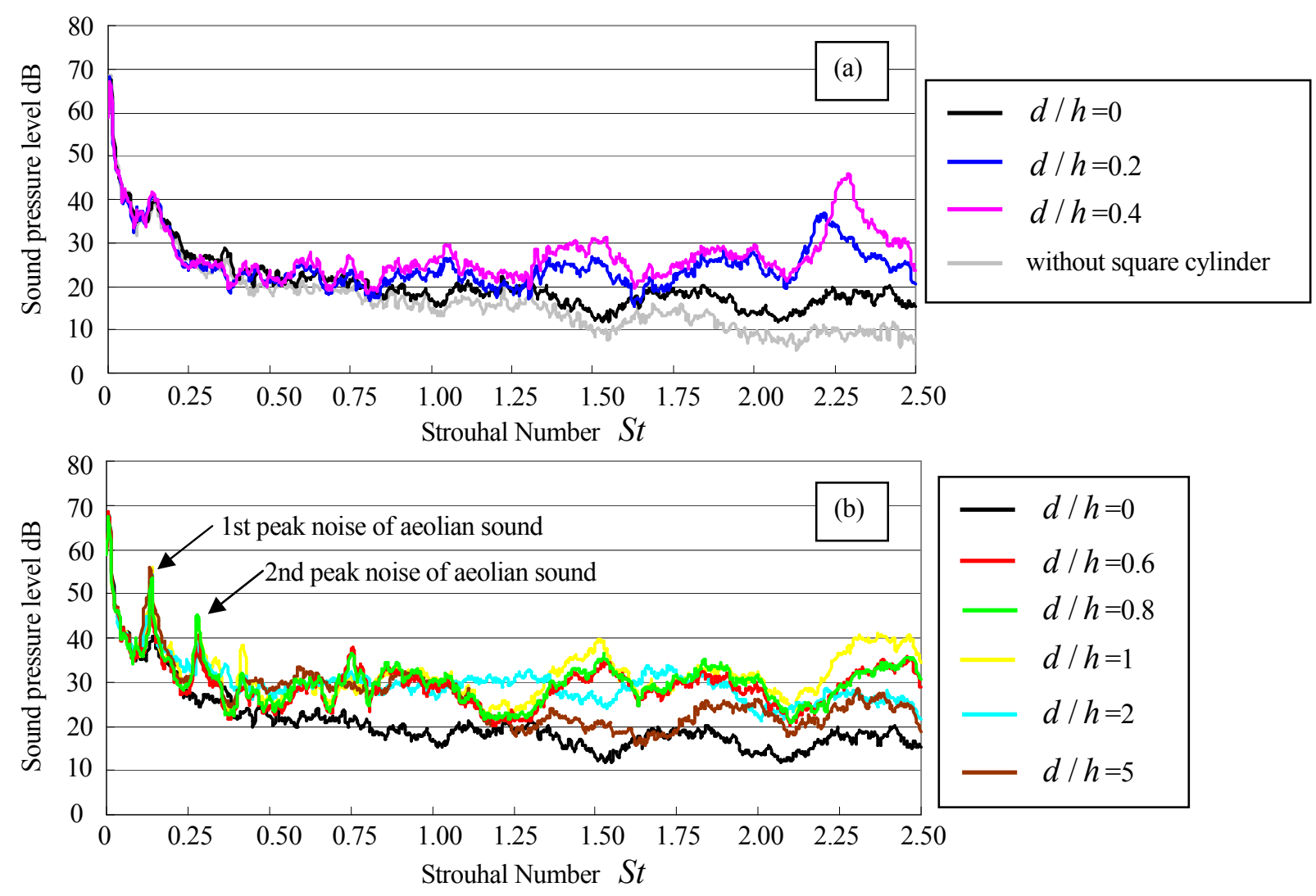

Fig. 3 Spectra of far-field noise level

\section{$5 \cdot 2$ 流れ場の検証}

角柱-平板間距離 $d / h=0$ の場合の, 油膜法による平板表面流線の可視化結果（図 4) を見ると, 角柱後方の剥 離領域は角柱スパン方向に一様に形成されていないことがわかる. 主流のスパン方向端部から中心側へ向かう流 線が存在し, その流線の一部は剥離領域へ巻き込まれている.この流れは, 数值解析による流線の可視化結果 (図 5）からも確認できる.このように角柱後方の流れ場は，2 次元的な剥離・再付着の流れ構造ではなく，3 次元的 な流れ構造となっている.

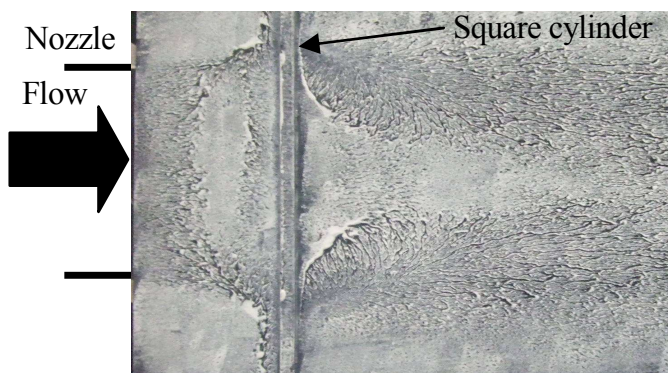

Fig. 4 Visualization of flow structure by oil flow method

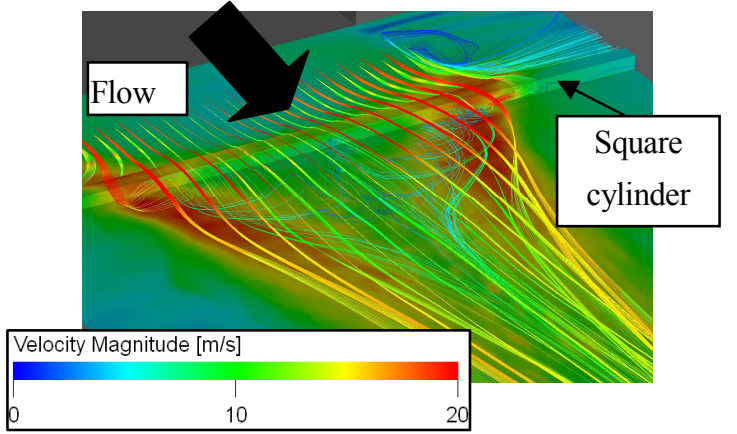

Fig. 5 Streamlines colored by velocity magnitude $(d / h=0)$

また, 本数值解析結果の精度を確認するため, 図 1 に示した平板上の各点において, 圧力変動の計測結果と計 算結果を比較した（図 6).ここでは, 時系列の圧力変動データを FFTによりナローバンドで周波数分析し, $\mathrm{dB}$ 值への変換は，基準圧力を $2 \times 10^{-5} \mathrm{~Pa}$ とした．また，空関数には八ニング空を用い，ウインドウのオーバラップ 


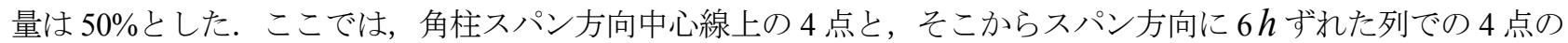
計 8 点の結果を示す. 点 1 , 点 5 , 点 6 では, 圧力変動レベルが定量的に一致していないが, その他の箇所では, 実験と数值解析の結果が概小定量的に一致している。このことから，数值解析結果は実際の流れ場を定性的に模 擬していると考えられる.
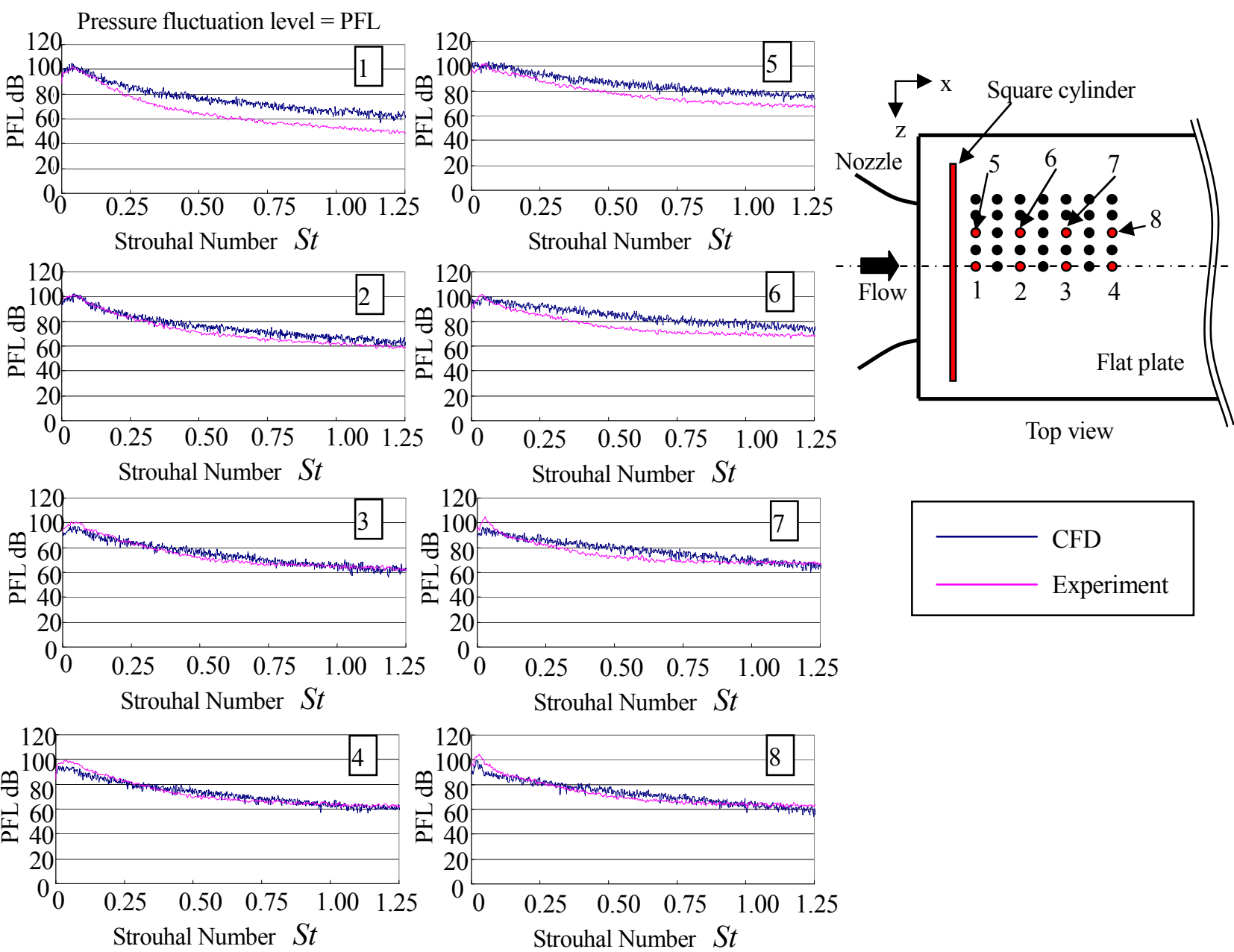

Fig. 6 Spectra of surface pressure fluctuations on flat plate $(d / h=0)$

数值解析結果から，角柱および平板上の圧力変動の周波数分析結果を $\mathrm{dB}$ 值の分布図として図 7 に示す。低周 波数帯域の例として $S t=0.063 \sim 0.19$ (図 7(a)), 高周波数帯域の例として $S t=0.50 \sim 1.25$ （図 7(b)）の分布図を示 す。低周波数帯域，高周波数帯域のいずれにおいても，圧力変動の大きい領域では，流線が渦巻いており，流れ が複雑に乱れている(図 5).

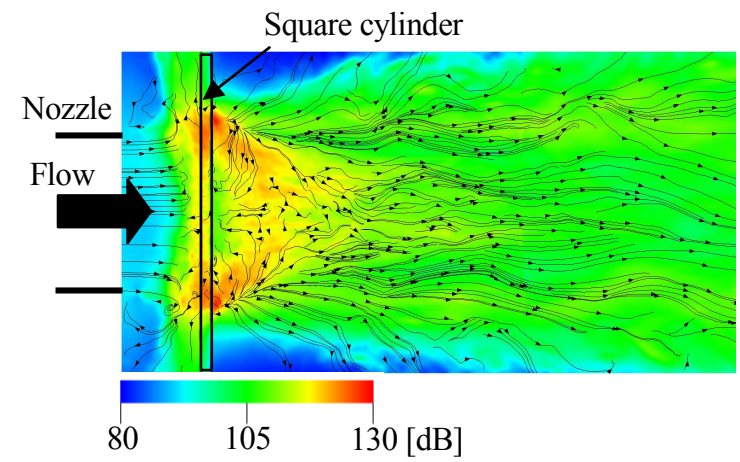

(a) $S t=0.063 \sim 0.19$

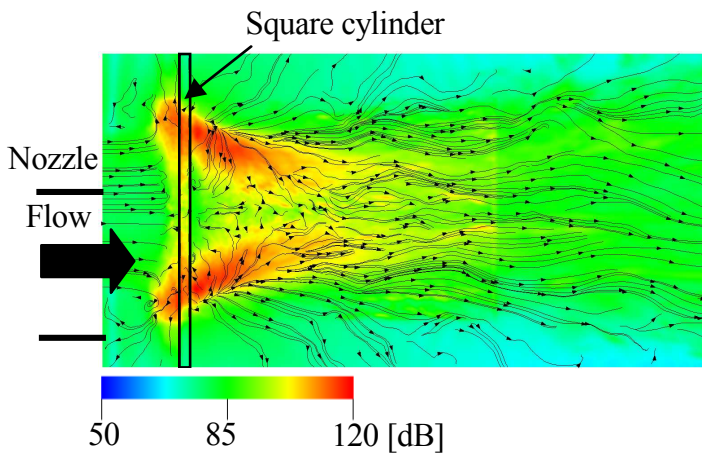

(b) $S t=0.50 \sim 1.25$

Fig. 7 Distribution of surface pressure fluctuations on the square cylinder and the flat plate $(d / h=0)$ 
一方, 角柱-平板距離 $d / h$ が 2 と 5 の場合の，角柱および平板表面の低周波数および高周波数帯域における圧 力変動レベルの分布を図 8 と図 9 に示す. いずれの結果からも, $S t=0.063 \sim 0.19$ では, 角柱表面上の圧力変動レ ベルが高い. また，図 10 を見ると，角柱スパン方向中心断面における $\mathrm{z}$ 軸回りの渦度分布から，角柱後流にカル マン渦が形成されていることが分かる. 図 11 は, 数值解析結果による角柱表面のスパン方向中心位置での圧力変 動スペクトルである.この結果から,$d / h=2$ と $d / h=5$ の場合, $S t=0.13$ 付近にピークが見られ, 実験結果ほ ど明瞭ではないものの, $S t=0.26$ 付近に 2 次ピークが確認できる. このことから,$S t=0.063 \sim 0.19$ の圧力変動レ ベル分布で角柱表面の変動レベルが高いのは，角柱後流のカルマン渦によるものと判断できる.また，図 8 と図 9 では, $S t=0.063 \sim 0.19, S t=0.50 \sim 1.25$ のいずれでも, 角柱近くの平板表面圧力変動レベルが $d / h=5$ の場合よ りも $d / h=2$ の方が高い. これは， $d / h=2$ の場合，角柱-平板間距離が十分大きくないため，後流と平板の干涉 が角柱近くで生じているためと考えられ，図 10 からその様子が確認できる. 一方， $d / h=5$ では, $d / h=2$ より も下流域で後流と平板の干渉が生じて, 圧力変動レベルが高くなっている.

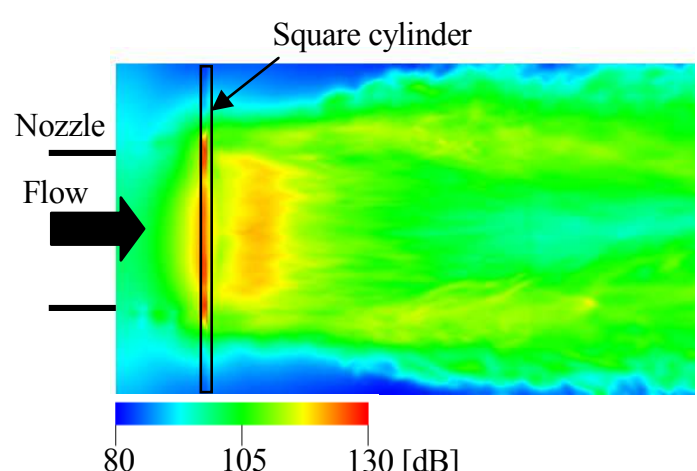

(a) $d / h=2$

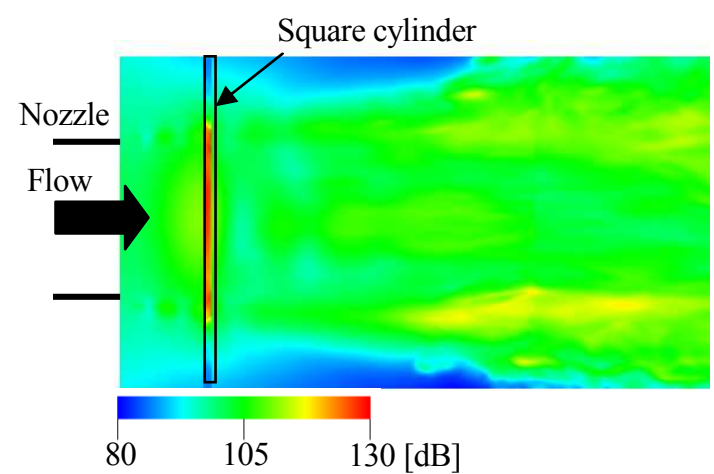

(b) $d / h=5$

Fig. 8 Distributions of surface pressure fluctuations on the surfaces of square cylinder and flat plate $(S t=0.063 \sim 0.19)$

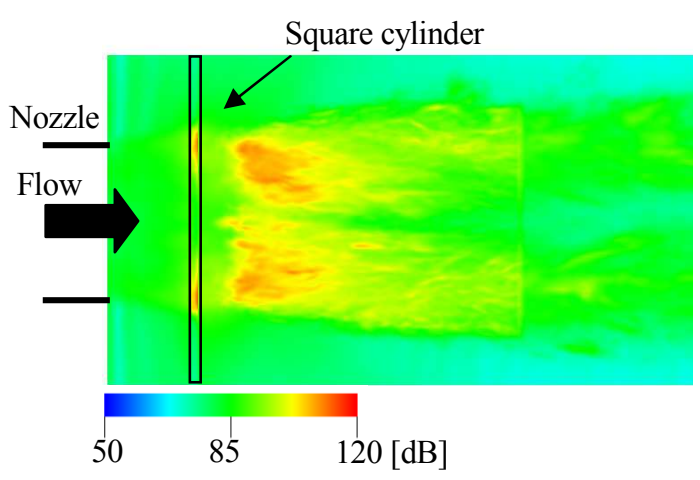

(a) $d / h=2$

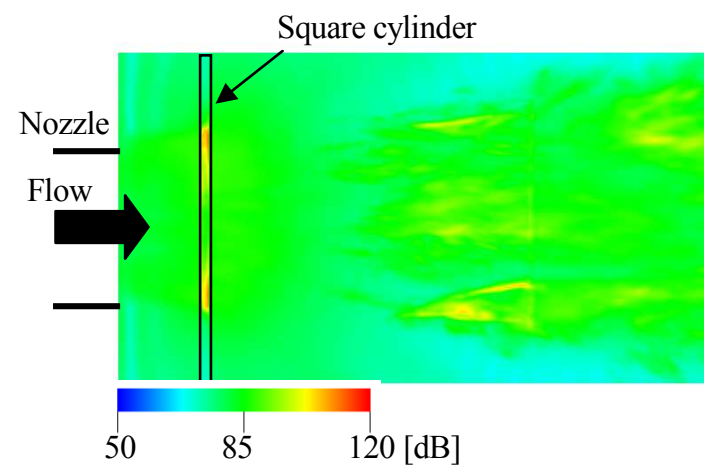

(b) $d / h=5$

Fig. 9 Distributions of surface pressure fluctuations on the surfaces of square cylinder and flat plate $(S t=0.50 \sim 1.25)$

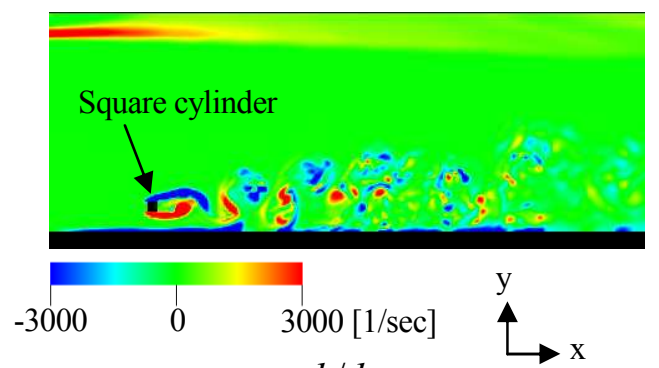

(a) $d / h=2$

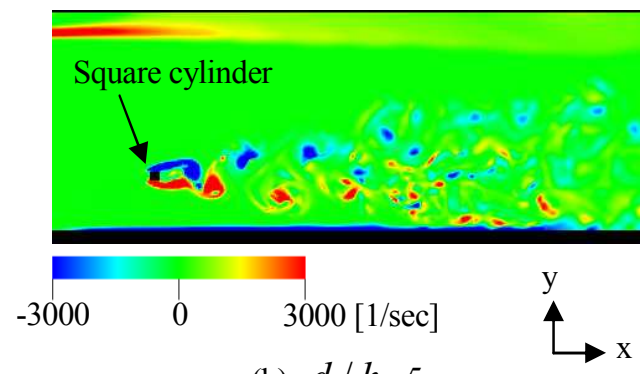

(b) $d / h=5$

Fig. 10 Contours of z-directional vorticity on x-y plane 


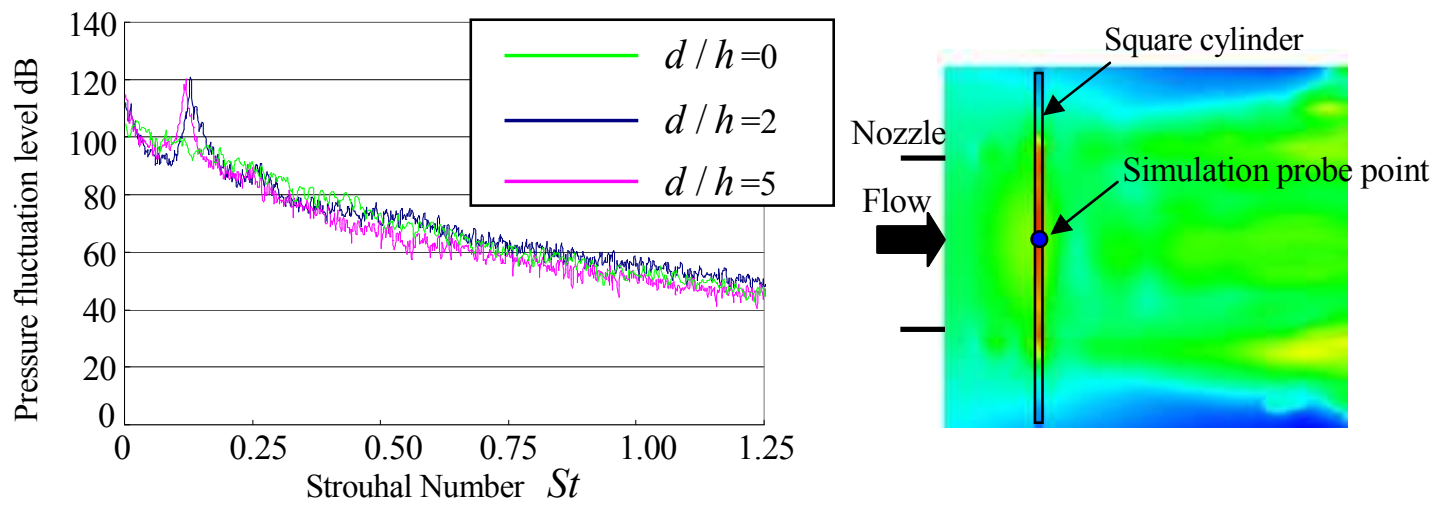

Fig. 11 Spectra of pressure fluctuations on the upper side surface point of square cylinder

\section{$5 \cdot 3$ 音場の検証}

空力騒音の基礎方程式である Lighthill 方程式は, 圧縮性を考慮した連続の式と, Navier-Stokes 方程式および音 速の定義式から厳密に導出される ${ }^{(5)}$.

$$
\begin{aligned}
& \frac{\partial^{2} \rho}{\partial t^{2}}-a^{2} \nabla^{2} \rho=\frac{\partial^{2} T_{i j}}{\partial x_{i} \partial x_{j}} \\
& T_{i j}=\rho v_{i} v_{j}+\delta_{i j}\left\{\left(p-p_{0}\right)-a^{2}\left(\rho-\rho_{0}\right)\right\}-\sigma_{i j} \quad \delta_{i j}: \text { クロネッカーのデルタ }
\end{aligned}
$$

式（3）の右辺が Lighthill 音源項である．また，式（4）は Lighthill テンソルで，添え字 0 は静止状態を表す．式 （4）の右辺第 1 項は対流によるレイノルズ応力項, 第 2 項は圧縮性による項, 第 3 項は粘性による項である. こ のように Lighthill テンソルは, Navier-Stokes 方程式の対流項に起因したレイノルズ応力項が入っているので, Lighthill 音源の非定常運動によって形成される圧力場には, 遠方場まで音速で伝播する音波に加えて, 対流によ って流れ場中やその近傍に局所的に発生する流体力学的な圧力変動を含んでいると考えられる. 本研究の流れ場 のような低マッ八数, 高レイノルズ数の流れ場では, 圧縮性および粘性力の影響が小さいため, Lighthill テンソ ルは式（5）で近似できる.

$$
T_{i j} \cong \rho v_{i} v_{j}
$$

式(3)の右辺にあるレイノルズ応力の空間 2 階微分に関連して, Lighthill 音源の分布を数值解析結果から求めた. 以降, 音源とは Lighthill 音源のことを指寸. 図 12 は, 瞬時の Lighthill 音源の等値面分布である. 角柱-平板距離 が $d / h=0,2$ の場合, Lighthill 音源は, 角柱と平板の両方の近傍に存在しており, $d / h=5$ の場合には, 角柱の 近傍にの夕分布している.

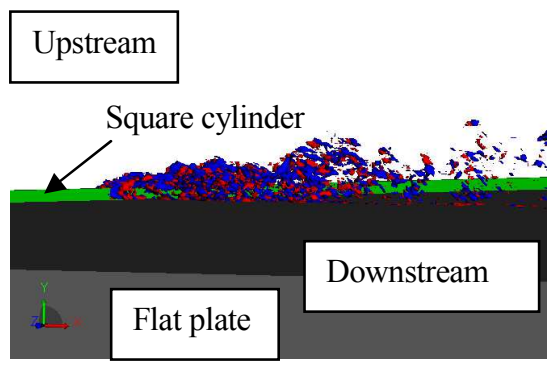

(a) $d / h=0$

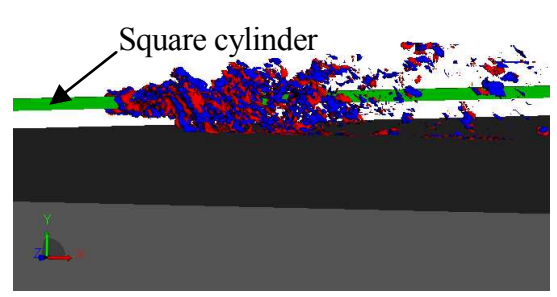

(b) $d / h=2$

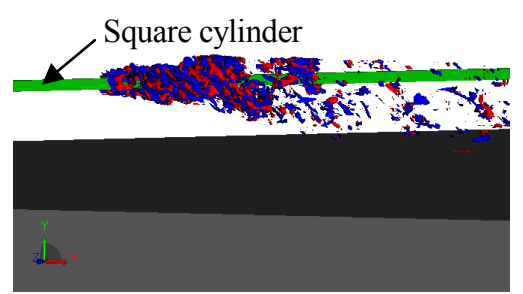

(c) $d / h=5$

Fig. 12 Iso-surfaces of instantaneous Lighthill acoustic sources 
音波の音圧レベルは音源からの距離の 2 乗に, また近傍場の圧力変動レベルは 4 乗に反比例して減衰するため (6), 近傍場における圧力変動は遠方場での音波に比べ, 音源からの距離の増加に伴い急激に減衰する. 遠方場と 近傍場の変動圧の比 $\xi$ は以下の式で表される(7).

$$
\xi=\frac{2 \pi f r}{a}=\frac{2 \pi r}{\lambda}
$$

ここで， $f$ は音の周波数で， $r$ は音源からの距離である. 式（6）より，波長の短い高周波数成分ほど，音源か ら短い距離で近傍場の圧力変動の影響が小さくなることがわかる. 例えば $d / h=0$ の場合, Lighthill 音源と平板 の距離は非常に近接しており，低周波数帯域から高周波数帯域まで平板上では対流による圧力変動が支配的とな る. 一方, 角柱-平板距離が $d / h=5$ の場合には, 気流と平板との干渉は弱く, 対流の圧力変動は主として角柱表 面上に誘起される. 波長の短い高周波数成分については, 平板表面に対流による圧力変動は誘起されにくい. し たがって，平板は音波の反射面として遠方場騒音に影響を及ぼすと考えらえる.

図 13 は, $S t=0.50 \sim 1.25$ における高周波数帯域の圧力変動（音圧）の瞬間值分布である. 空間および物体表面 の時系列の圧力データを FFT 解析し, $S t=0.50 \sim 1.25$ の周波数成分のみをバンドパスフィルタにより抽出した後, 逆フーリエ変換を行った. 角柱-平板距離が $d / h=0$ の場合, 平板表面上に波数の多い対流による圧力変動成分が 確認できる. 一方, $d / h=5$ の場合, 下流域では, 平板上に対流の圧力変動成分が見られるが，角柱よりも上流 側から角柱真下付近の平板表面上では, 音波のみが分布している. この結果から, $S t=0.50 \sim 1.25$ などの高周波 数帯域においては, 角柱-平板距離が大きくなるにつれ，平板が流れ場に及ぼす影響が小さくなり，平板は角柱上 流側から真下付近において音波の反射面としてのみ機能していると考えられる.

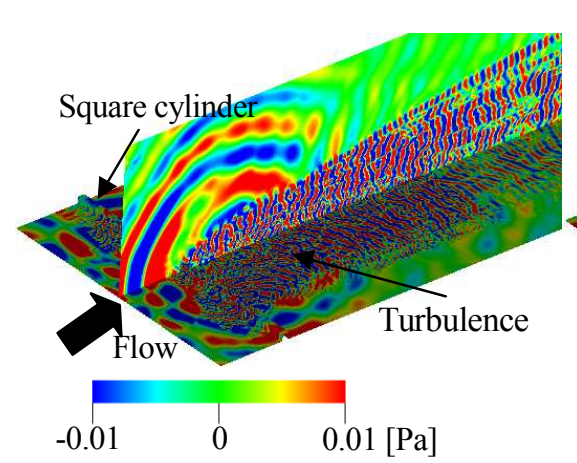

(a) $d / h=0$

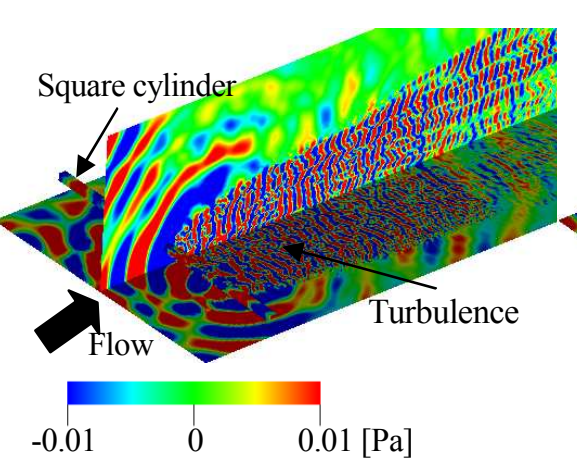

(b) $d / h=2$

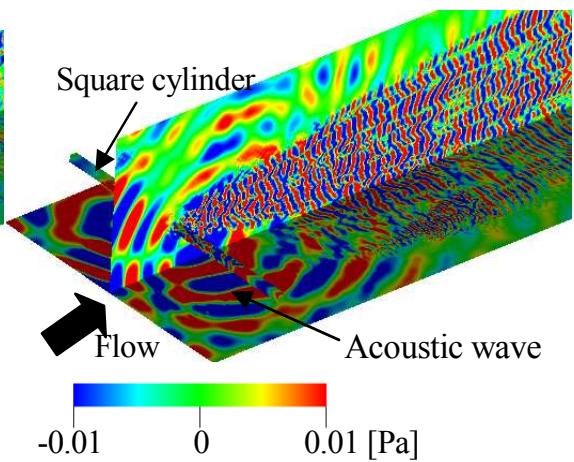

(c) $d / h=5$

Fig. 13 Instantaneous pressure fluctuations $(S t=0.50 \sim 1.25)$

音源領域がコンパクトであることを前提とした遠方場音圧に対する音の放射効率 ${ }^{(8)}$ は, 2 重極音がマッハ数の 3 乗に比例し，4 重極音が 5 乗に比例する. その結果，低マッ八数流れでは，2 重極音が遠方場騒音に対して支配的 となる. Lighthill 理論に静止した物体面の影響を加えた Lighthill-Curle の式(9)を音源がコンパクトである条件のも と簡略化して, 物体表面の圧力変動 $(\partial p / \partial t)$ によって遠方場騒音レベルが評価できることは広く知られている. しかし，本研究で扱っている角柱と平板で構成される基礎模型は，今回計測対象とした周波数範囲では，発生騒 音の波長に対して物体のスケールが十分小さいという条件を満たしておらず(10)，音源はコンパクトではなく，非 コンパクトな音源と見なすべきである ${ }^{(10)}$. よって,物体表面の圧力変動により，解析的に遠方場騒音レベルの大小 を評価することはできない．実際に $S t=0.50 \sim 1.25$ の周波数範囲においては，角柱および平板表面の圧力変動レ ベルは, $d / h=0$ の場合が最も大きいが(図 7 9), 遠方場騒音レベルでは, $d / h=0$ のときが最も小さい(図 3(b)). すなわち, 物体表面の圧力変動レベルと遠方場騒音レベルの大小関係に相関は見られない. 
平板が，遠方場騷音レベルに及ぼす影響を実験により確認した（図 14）。平板を設けることで，角柱-平板間距 離 $d / h=0$ 以外の場合, $S t=0.25$ よりも高周波数帯域で音圧レベルが増大している ( $5 \mathrm{~dB}$ 以上変化している周波数 もある)。つまり，高周波数帯域における遠方場騒音に対する反射音の影響は大きいことが分かる.

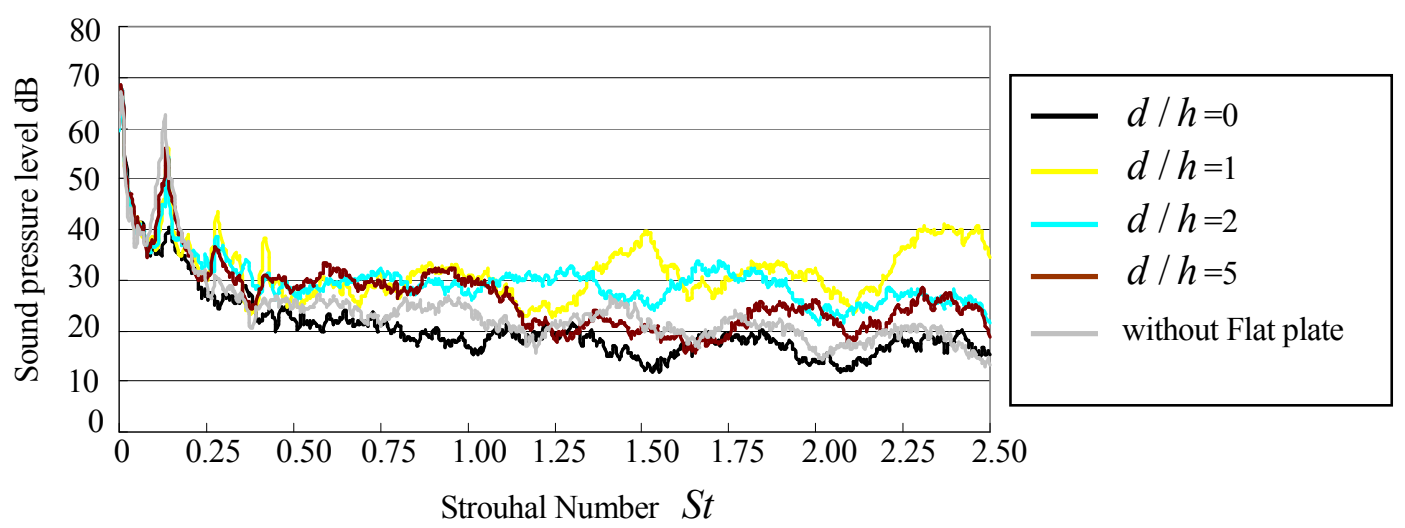

Fig. 14 Spectra of far-field noise without flat plate

\section{6. 結 言}

角柱と平板からなる基礎的な模型を用いて, 角柱-平板間距離を変化させた場合の流れ場と音場を実験および数 值解析により調べた。得られた知見を以下にまとめる.

（1） 角柱-平板間距離 $d / h$ をパラメータとして遠方場騒音を計測した結果， $d / h \geqq 0.6$ では角柱後流にカル マン渦が形成され，エオルス音を発生させることが分かった．また，これに加えて，St>0.50 の周波数 帯域での騒音レベルも上昇することが確認された.

（2）平板上に角柱を設置することにより, 角柱後流と平板の干渉が強まると推察される. その結果, 発生騒 音の音圧レベルが上昇すると考えられる. 騒音計測結果から, $d / h<0.6$ では, 角柱-平板間に隙間が生 じると， $S t>0.90$ における遠方場騒音レベルが大きく増大寸ることが分かった.

(3) $d / h \geqq 0.6$ では, 角柱-平板間距離が大きくなるにつれ, 平板には対流による流体力学的な圧力変動が誘 起されにくくなる. しかし, 角柱後流と平板の干渉が弱まっても, 平板は, 音波の反射面としての機能 を持ち，遠方場騒音に影響を及ぼす。

（4）供試模型のように音源を誘起する物体の近傍に平板を設けることで，音源のコンパクト性が成立しなく なり，物体表面の圧力変動のみでの遠方場騒音レベルの大小を評価することはできなくなる．角柱-平板 間距離の変化に伴い，音源からの直接音と平板反射音の計測点までの経路差が変化する．このことから 両者が干渉するとき, その位相差が変化して, 音圧レベルの大小関係が周波数ごとに変化すると考えら れる. 


\section{文献}

（1）日本建築学会編，騒音の評価法，第 1 版 (1981), p. 17, 彰国社.

(2) Nouzawa, T., Li, Y. and Nakamura, T., "Mechanism of Aerodynamic Noise Generated from Front-Pillar and Door Mirror of Autobobile", Journal of Environment and Engineering, Vol. 6, No. 3 (2011), pp. 615-626.

(3) 岡島厚，杉谷賢一郎，”長方形断面柱のストローハル数と背圧係数(レイノルズ数の影響)”, 日本機械学会論文集 B 編，Vol. 50, No. 457 (1984) ,pp. 2004-2012.

(4) 高石武久, 佐川明朗, 加藤千幸, ” 非コンパクトグリーン関数を用いたパンタグラフ空力音の数值解析”, 日本機械 学会論文集 B 編, Vol. 74, No. 745 (2008), pp. 1910-1919.

(5) Lighthill, M.J., "On sound generated aerodynamically I. General theory”, Proceedings of the Royal Society of London, A1211, (1952), pp. 570-571.

(6) 飯田明由, 藤田肇, 加藤千幸, 大田黒敏夫, ” 空力音の発生機構に関する実験解析(第 2 報, 表面圧力変動と空力音 の相互相関)”，日本機械学会論文集 B 編，Vol. 62, No. 604（1996）,pp. 4160-4167.

(7) 横野泰之, 藤田肇, ”スーパーコンピュータを用いたステアリングシステムによる角柱から放射される空力音の数 值解析”，日本機械学会論文集 B 編，Vol. 61, No. 583 (1995）, pp. 947-952.

(8) 吉川茂, 和田仁, 音源の流体音響学, 初版 (2008), p. 113-114, コロナ社.

(9) Curle, N., "The Influence of Solid Boundaries upon Aerodynamic Sound”, Proceedings of the Royal Society of London, A231, (1955), pp. 504-514.

(10) Howe, M. S., Theory of Vortex Sound (2003), p. 17-18, 37-39, Cambridge University Press. 